\title{
Pandemic Crisis in Online Media: Quantitative Framing Analysis on detik.com's Coverage of Covid-19
}

\author{
Justito Adiprasetio ${ }^{1}$, Annissa Winda Larasati ${ }^{2}$ \\ ${ }^{1}$ Department of Mass Communication, Faculty of Communication, Universitas Padjadjaran \\ (email: justito.adiprasetio@unpad.ac.id) \\ ${ }^{2}$ The Graduate School, Universitas Gadjah Mada (email: anisawindalarasati@gmail.com)
}

\begin{abstract}
This study shows how detik.com, a pioneer and one of the largest online media companies in Indonesia frames the Covid-19 pandemic crisis. From the 6713 news reports in January, February and March, the most dominant framing of the crisis that appeared in the coverage was attribution of responsibility, followed by frame of human interest, frame of morality, frame of conflict and the last is frame of economic consequences. The quantitative approach was used in this research to ensure that systematic analysis and non-arbitrary procedures can be carried out on large amounts of data. This study offered a better understanding on of how online media framed the crisis during the pandemic. The results of this study indicate that the frame of attribution of responsibility is not only the most widely used by detik.com, but also the most dominant when the government is the main source of the news. The form of attribution of responsibility in times of crisis tends to be stronger in the realm of government because crisis events are widespread, forming an experience felt at the national level. As a result, crisis events have the potential to become political symbols used in framing various debates regarding a policy in the long run. The average tone of news towards the government from January to March was positive, although it gradually became more negative.
\end{abstract}

\section{Keywords:}

Framing; Crisis; News Source; Covid-19; Tone; Covid-19 Pandemic

\section{Introduction}

The Covid-19 (Coronavirus disease 2019) pandemic is currently spreading throughout the world. As of May 29, 2020, more than 5.9 million cases have been reported worldwide across every continent, in more than 188 countries. Although 2.39 million people have recovered, 359 thousand people have died as a result of Covid-19 virus ("COVID-19 Map Johns Hopkins Coronavirus Resource Center," 2020). Covid-19 is an infectious disease caused by severe acute respiratory syndrome coronavirus type 2 (SARS-CoV-2). In Indonesia as of May 29, 2020 there were 24538 confirmed cases of which 1496 people have died, and 6240 have recovered ("Peta Sebaran COVID-19," 2020). In the Covid-19 pandemic crisis, the mass media play a crucial role as sources of information. A study published by Time shows that the amount of news articles about the Covid-19 outbreak in 2020 are significantly larger than the coverage of the Ebola outbreak in 2018 (Ducharme, 2020). A similar thing happened in Indonesia. We found that in the first three months of the pandemic (January-February-March), detik.com, one of the most popular online media companies in Indonesia has published 6713 articles reporting on the Covid-19 pandemic crisis.

Media coverage on a pandemic crisis is never a simple reflection of health issues that have an impact on society. There is a pattern of media coverage that shows a competition 
process among various factors that influence news reports (Blumer, 1971; Johnson-Cartee, 2005; Vreese, 2005; Lecheler \& De Vreese, 2018). How media frame pandemics and health issues shape our understanding of the meaning of health and various perceptions of healthrelated discourse maps (Berry, Wharf-Higgins, \& Naylor, 2007). Basnyat and Lee (2015) for example, analyzed how media coverage related to the H1N1 pandemic in 2009 reflected the frame and mediation of the flow of information, reinforcing a positive tone toward government, emphasizing individual responsibility and a framework that Singapore as a nation-state is a country which is strong and resilient to a pandemic. Abeysinghe and White's study (2010; 2011) found that collective memory of the Spanish flu that occurred decades ago was mediating Avian Influenza pandemic crisis frames in Australia. The frame becomes part of a symbolic solution in controlling and mitigating the spread of Avian Influenza. Whereas Hong (2007) showed that when the SARS pandemic crisis occurred in 2003, Chinese national newspapers used health severity frames more often than Chinese regional newspapers.

Existing studies show that in general, news has a bias in the tone of its content: positive-negative or in a balanced situation, neutral (Waldman \& Devitt, 1998; D' Alessio \& Allen, 2000; Kiousis, McDevitt, \& Wu, 2005). The same thing also happened with the tone of news content relating to crisis situations such as a pandemic. The tone which media use to disseminate information tells the audience not just news, but also the opinion of a particular reporter. Tone, or valence, is one more part of media framing that influences audience members to think a certain way about a particular issue. Therefore, one of the things that become the focus of this study is the tone of news toward government regarding the Covid-19 pandemic crisis on detik.com.

detik.com itself is a pioneer of online media and is very dominant in online media reporting in Indonesia (Margianto \& Syaefullah, 2013). detik.com currently occupies the fourth position as the most visited news site in Indonesia after okezone.com, tribunnews.com, grid.id (the ranking is based on alexa.com, May 28, 2020). detik.com is a benchmark for online media coverage in Indonesia, because it relies on speed, accuracy and quantity (Margianto \& Syaefullah, 2013).

There are various problems in news coverage of the Covid-19 pandemic in Indonesia. We can see how the media often frame the issues carelessly, and broadcast without sufficient curation and verification (Adiprasetio, 2020a). Media in Indonesia for example, is deemed not to play an appropriate and significant role in terms of appropriate disaster mitigation efforts (Herlinda, 2020). Furthermore, Indonesian media is also accused of not building a sense of crisis for the society; the majority of mass media only broadcast news from one side only, such as the government and various authorities and tend to underestimate the statements of medical personnel or other non-Indonesian governmental authorities (Adiprasetio, 2020a). There is an intention to provide a portion of the narrative to the government where the government is often used as the main source of information.

Iyengar (1992) explains that there are two frames on how the media construct social issues. The first is the thematic frame, where patients infected with Covid-19 will not be described by simply explaining one accidental event, but media will try to relate it to a larger context and setting such as the government's late handling of Covid-19 or the country's unpreparedness towards a crisis situation. The second is the episodic frame, which sees an event singly and ignores the context behind it. In general, news reporting that uses an episodic frame will tend to benefit the position of the government and neutralize the negative tone of reporting against the government (Iyengar, 1992). This is because stories about Covid-19 patients, for example, will be seen episodically, 
and the context of the government's role on handling it, is ignored.

Based on the explanation above, the research objectives of this study is to show how the framing configuration is based on the crisis framing types and; which parties are dominant and are often the main informants in the news; in addition, there is an identification tone of reporting to the government regarding Covid-19. This study used contingency table or cross tabulation analysis to analyze the simple relationship between several variables.

The Research Questions (RQ) in this study are:

RQ (1). Who are the sources of news on detik. com in framing the Covid-19 crisis?

RQ (2). What is the average tone of Covid-19 crisis news on detik.com toward the government? RQ (3). How is the crisis frame used for Covid-19 on detik.com?

RQ (4). What is the comparison between thematic frames and episodic frames on detik. com in Covid-19 crisis news?

\section{Literature Review}

Framing is the process in which an entity: a person or mass media develops a particular conceptualization of a problem or redirects thinking on an issue (Chong \& Druckman, 2007). Whereas the premise of media framing analysis is how information about an issue presented in a news report will potentially influence the assessment of these issues (Entman, 2007).

Framing itself is a theory in media analysis which has been widely applied to news related to politics (Iyengar, 1990a; Iyengar, 1990b; Iyengar, 1991; De Vreese, 2004; Becker \& Scheufele, 2011), disasters (Entman, 1991; Merry, 2015; Haider-Markel, Delehanty, \& Beverlin, 2007), racism and sexism (Poindexter, Smith, \& Heider, 2003; BenPorath \& Shaker, 2010), conflict (Adiprasetio, 2020b) and terrorism (Norris, Kern, \& Just, 2003; Papacharissi \& Oliveira, 2008). Framing has also been used to analyze news related to the Covid-19 pandemic in Indonesia (Boer, Pratiwi, \& Muna, 2020; Palupi \& Irawan, 2020; Hayati \& Yoedtadi, 2020).

In a variety of existing literature, framing can also be related to media effects (Price \& Tewksbury, 1997). Framing has been called a perspective (Kuypers, 2005; D' Angelo \& Kuypers, 2016), a paradigm (Entman, 1993), an approach (Detenber \& McLeod, 1999; Pan \& Kosicki, 1993), an analytical technique (Endres, 2004) and a multi-paradigmatic research program (D'Angelo, 2002).

There are two approaches in framing analysis: qualitative and quantitative. Qualitative analysis itself is divided into two types; first, using hermeneutic-qualitative and second; systematic techniques (D'Angelo \& Kuypers, 2016). Hermeneutic-qualitative procedure itself has weaknesses because many of its techniques are arbitrary and unsystematic (Tankard, 2001). As exemplified in previous research studies, (Dijk, 2011 and Pan \& Kosicki, 1993)a qualitative approach using systematic techniques by analyzing syntactical, thematic, rhetorical, and script structures in detail collided with their limitations in analyzing large amounts of data.

Another approach is quantitative which is divided into holistic techniques and device oriented techniques (D'Angelo \& Kuypers, 2016). Device oriented techniques will rely on indicators or frame elements consisting of words (Entman, 1991) or argument structure (McComas \& Shanahan, 1999). The quantitative approach was used in this research to ensure that systematic analysis and non-arbitrary procedures can be carried out on large amounts of data. This study used holistic techniques, in which analysis of media frame coding refer to the previous studies (Nisbet, Hart, Myers, \& Ellithorpe, 2013). This study refers to the frames of crisis previously described in the An and Gower (2009) study.

The study of framing used to analyze the pandemic in Indonesia tends to be dominated 
by a qualitative approach (Boer, Pratiwi, \& Muna, 2020; Palupi \& Irawan, 2020; Hayati \& Yoedtadi, 2020), as well as adopting a hermeneutic procedure. That makes the analysis related to the media coverage frame of the Covid-19 pandemic not systematic, and are always in micro analysis. This study seeks to obtain analysis with a large data population, so that findings would make a distinctive contribution to how online media in Indonesia has framed the Covid-19 pandemic crisis at a macro level.

\section{Methods}

This study used a quantitative framing approach with holistic techniques, with the operationalization of the following variables:

\section{Operationalizing Variables News Sources}

Frames is the output of how news sources frame the issue, then proceed with renegotiations between reporters, writers, editors and news organizations involved in producing the news. The frame will represent the logic, ideology and genre of news from the actors involved in the production of the news (Entman, 2007; D’Angelo \& Kuypers, 2016).

This study examines the proportion of government and various non-government sides as sources in the news coverage of Covid-19. The codification process would be carried out by identifying the most dominant news sources: the frequency of statements and the number of words quoted by the media. The codification process is carried out by classifying news based on four categories: Indonesian government, non-Indonesian governmental authorities, the political opposition and the society.

\section{Tone Toward Government}

Several studies show that in any conflictrelated news reporting there will be a dominant tone, depending on the choice of media, habits and the influence of the media system in the production of the news text (Shoemaker \& Reese, 2014; Dunaway, 2013; Dimitrova \& Connolly-Ahern, 2007; Pfau et al., 2015). The news related to Covid-19 that we aim to identify in this study is the tone of detik.com news towards the government.

According to Nijkrake, Gosselt, \& Gutteling (2015), tone can be coded on a fivepoint Likert scale (ranging from very negative to very positive). The following values are: -2 , $-1,0,+1$ and +2 , to measure the tone.

\section{Type of Crisis Frames}

An and Gower (2009) show what frames are contained in the news and used national newspapers in covering news about crisis communication throughout 2006. Previously some literature had discussed the usual frames used in the news. Neuman, Just, and Crigler (1994) discuss holistically about certain types of frames which are often used in newspaper articles in the United States: conflict, economic consequences, human impact and mortality. While Semetko and Valkenburg, (2000) identified five dominant news frames: human interest, conflict, morality, economic, and attribution of responsibility, on five types of national newspapers and television news during the Amsterdam, European Council period in 1997. An and Gower (2009) adopted five frames that had previously been identified by Semetko and Valkenburg (2000). This study uses five frames that are also used by An and Gower (2009) to analyze news framing of the Covid-19 pandemic crisis on detik.com.

\section{Frame of Human Interest}

This frame focuses on the face and emotional side of humans towards an event, issue and problem in a crisis situation, this frame gives a psychological influence on humans, which directs the reader or audience to show various negative behaviors in a crisis (An \& Gower, 2009; Kim \& Cameron, 2011). Cho and Gower (2006) show that this 
frame influences the emotional response of the reader, which influences how the reader determines who is guilty and responsible in a crisis situation.

\section{Frame of Conflict}

Frame of conflict are used to show disagreement and conflict between individuals, groups or organizations. Based on the study of Semetko and Valkenburg (2000), the conflict rate is the second most common framework used in reporting. The more serious the news media, the more frames of conflict are in evidence.

\section{Frame of Morality}

This frame places events, problems or issues within the scope of moral, social prescription, and religious teachings. Neuman et al. (1994), show that moral frames are generally and indirectly used by journalists through quotations or inferences, rather than directly because of the various norms of objectivity in journalism activities.

\section{Frame of Economic Consequences}

Economic consequences frame reports an issue, problem or event related to its economic consequences on an individual, group, organization or country. Economic consequences are considered to have great news value because the economic consequences resulting from certain events can have a large impact on individuals, communities, organizations, countries and even the whole world (Graber \& Dunaway, 2018). Neuman et al. (1994) identify this as a general framework in reporting.

\section{Frame of Attribution of Responsibility}

This frame is defined by Semetko and Valkenburg (2000) as "a way of linking responsibility for finding solutions or solving problems, either to the government or to individuals or groups". Based on previous studies, serious media tends to use the frame of attribution of responsibility in its news (Iyengar, 1990a; Iyengar, 1991; Semetko \& Valkenburg, 2000). The presence of each frame in the news would be measured on a nominal scale of 1 (any) or 0 (none).

\section{Thematic and Episodic Frame}

Iyengar (1991) and An and Gower (2009) identified that there are two differences in the news frame in responding to a matter: Episodic News Frame and Thematic News Frame. Episodic News Frames focus on specific individuals or specific events, while Thematic News Frames show problems and events in a more general context or generalized over society or government. In this study, we examine the proportion of thematic frames and episodic frames on detik.com's coverage of Covid-19.

The existence of each frame in the news would be measured with a nominal scale of 1 (thematic frame) or 2 (episodic frame).

\section{Population: Corpus of News}

The focus of this study is news stories that are related to the Covid-19 pandemic crisis in January, February and March on detik.com. The data collection process is done by manually following time-based reporting on detik.com, from April 16 - 30, 2020. After that, the results would be synchronized to reduce the risk of news coverage that is not summarized.

The total number of news stories on detik. com that contain Covid-19 Pandemic Crisis discourse (The object analysis of this study is any news article with "Covid-19" in the title or at least found in the first paragraph of the news article) from January to March are 6713 news stories where 5917 news stories (88.14\%) were straight news, while 796 news articles $(11.86 \%)$ were features. In this study, we used all of the news as the data which then would be analyzed.

This unequal ratio between straight news and features can be reasonable, especially 
considering the position of detik.com which introduces a form of online journalism that relies on speed. The majority of news stories on detik.com are very short and partial since the element of journalism, $5 \mathrm{~W}+1 \mathrm{H}$ (who, what, where, when, why, how) is often split and published through separate posts (Margianto \& Syaefullah, 2006).

The following is a graph of the fluctuations in straight news and features from January 13 to March 31, 2020.

There was a significant increase in news reports in January with a total of 564 news stories (477 straight news and 87 features), to 2092 in February (1724 straight news and 368 features). The number increased significantly to 4057 in March (3716 straight news and 341 features). Dynamics of the increasing numbers over the period would be analyzed based on research questions posed by this study.

\section{Coding Procedures}

In conducting the reliability test the researcher used two intercoders (the people who did the coding to determine the reliability test results). Each coder coded all articles independently. Based on a sample of $5 \%$ of the entire unit of analysis, that is 336 news stories, two intercoders conducted a reliability test. Research reliability test analysis was done using Krippendorff's alpha $(\alpha)$ because of its more flexible nature. Krippendorff's alpha $(\alpha)$ can account for different levels of coding (i.e., nominal, ordinal, interval, and ratio), multiple coding categories, chance agreement, missing data, and different sample sizes (Krippendorff, 2005). The minimum limit of Krippendorff's alpha to be said to be reliable is 0.7000 in q $=0.0125$ (Hayes \& Krippendorff, 2007). The two variables tested for reliability are Tone to Government and Crisis Frames.

This reliability calculation uses the SPSS version 25 application program. The reliability test results in this study are as follows:

\section{Table 1.}

\section{Reliability Test Results}

\begin{tabular}{llr}
\hline \multicolumn{1}{c}{ Variable } & \multicolumn{1}{c}{ Sub-Variable } & \multicolumn{1}{c}{ Reliability } \\
\hline Tone to & & 0,7666 \\
$\begin{array}{l}\text { Government } \\
\text { Crisis Frames }\end{array}$ & Frame of Attribution of & 0,7951 \\
& Responsibility & \\
& Frame of Conflict & 0,764 \\
& Frame of Morality & 0,8182 \\
& Frame of Human & 0,7654 \\
& Interest & \\
& Frame of Economic & 0,8634 \\
& Consequences & \\
\hline
\end{tabular}

Source: Obtained from Reliability Test in SPSS

\section{Graph 1.}

The Fluctuation of detik.com News in January-March 2020

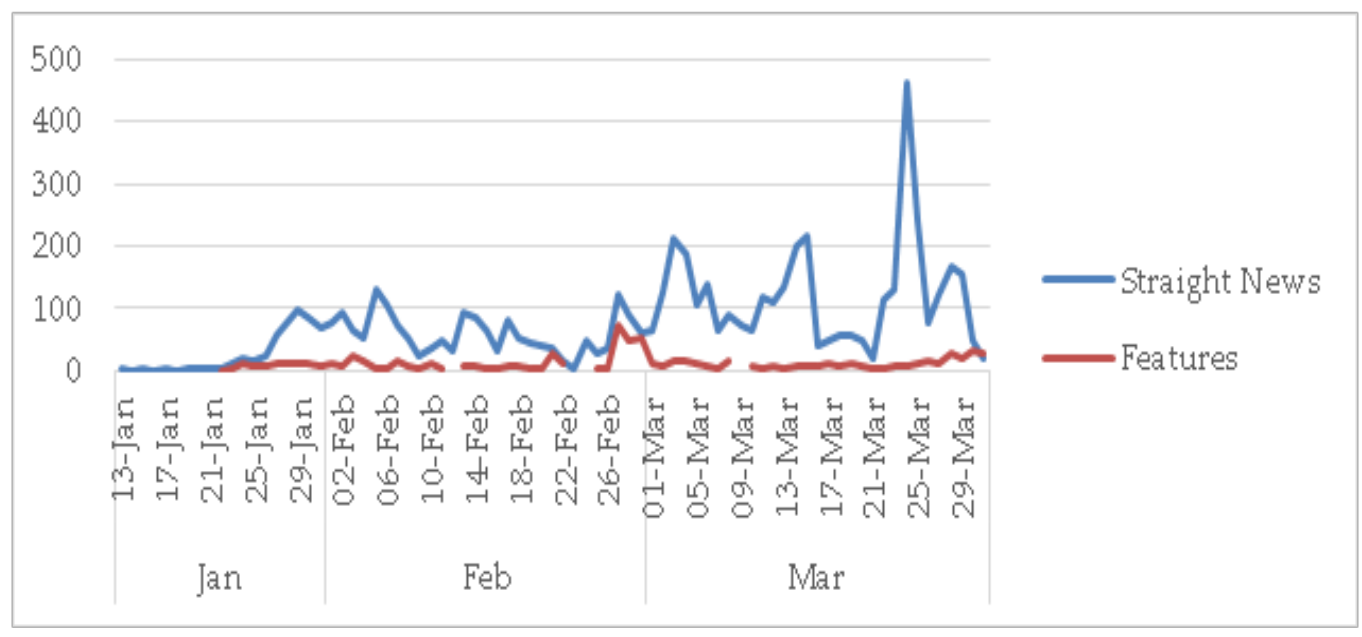

Source: Obtained from the results of the codification. 
Based on the reliability test results it can be concluded that the coding process is reliable, since the Krippendorff's Alpha number is above $>0.7000$.

\section{Cross Tabulation}

Cross tabulation is a type of table in a matrix format that displays the (multivariate) frequency distribution of the variables. Cross-tabulation is used to explore simple relationships between two existing variables and help find interactions between them (Lavrakas, 2011).

In this study, we used cross-tabulation as an additional analysis to show the simple relationships between the variables. This simple relationship contributes to the analysis and secondary discussion of the findings of this study. There are three cross-tabulations conducted in this study: cross-tabulation between average tone and news source; Crisis Frames with news source and average tone towards government with a thematic / episodic frame.

\section{Results and Discussion \\ News Source (RQ1)}

Based on data from January 13 to March 30,2020 , we found that the main source of reporting was the Indonesian government. Of the 6713 news stories about the Covid-19 pandemic crisis, over 3 months, 4376 (65.19\%) refer to the Indonesian government as the main source; 1300 (19.37\%) from the Non-Indonesian governmental authorities; 424 (6.31\%) came from the government's political oppositions and $613(9.13 \%)$ from the society.

Even though there are fluctuations, we can see reports that cited Indonesian government as the main source of information almost always occupy the top and dominant position. Every time government issued an official statement, news reports that make the government as a news resource also multiplied. Based on observations, this is due to journalists trying to verify and synchronize when there is a statement of one element of the Indonesian government's authority with another authority. As happened on March 2, 2020 when President Joko Widodo announced the first two Indonesian citizens who tested positive in Depok, West Java, the media then covered other government authorities at various levels: Indonesian Ministry of Health, Regional Government, etc. to further elaborate the report about the spread of the Covid-19 pandemic crisis in Indonesia.

\section{Graph 2.}

The Fluctuation of detik.com Main News Sources in January-March 2020

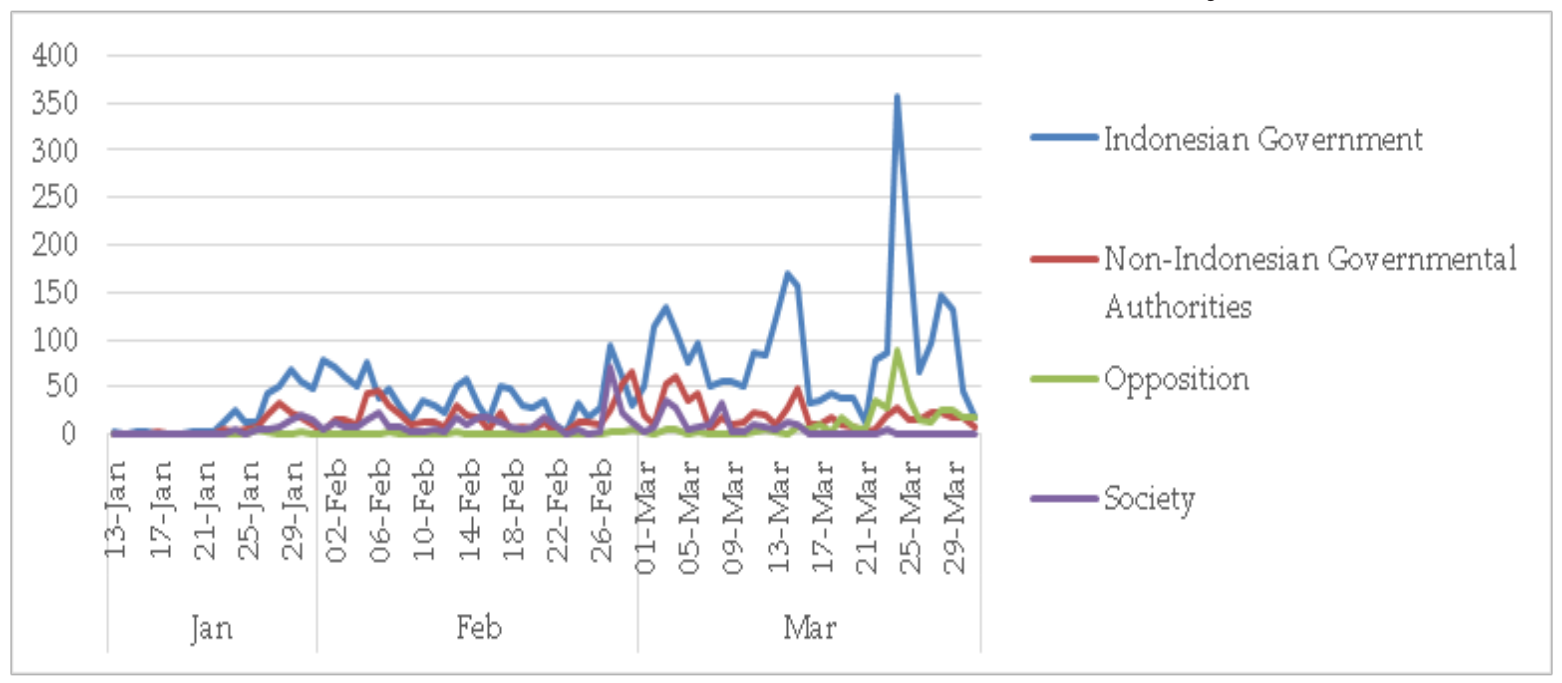

Source: Obtained from the results of the codification. 
Non-Indonesian governmental authorities are used as the news sources only on two days: February 6, 2020 and February 29, 2020, before President Joko Widodo submits the first positive cases in Indonesia. At these two moments based on data analysis, non-government health authorities: academics, researchers, healthrelated research institutions, etc. became the main source of news who explained about the overall impact of Sars-CoV2 for the patients and society. Aside from the health authorities, non-Indonesian governmental organizations, academics and economic researchers also became the main speakers who explained what Covid-19 meant for the world economy and Indonesia. However, after March 2, 2020, Indonesian government narratives dominate all issues related to the Covid-19 pandemic crisis, including for health and economic problems.

The elements of the society - individual or community representative, ranked third as the most frequent news source: January with 76 news articles, February with 350 news stories and in March, 187 news stories. Based on this data, we can see the narratives that make the society the main element, decreased by almost half from February to March 2020. This happened along with a significant increase in the number of reports that made the Indonesian government the main source. Meanwhile, the political opposition - those who are politically opposed to the government: joining in an opposition party or independently taking a position opposite to the government in a political realm - received little place in the media as the new source: January, 8 news and February, 21 news. However, in March, their appearance in the news was increasing with 395 reports which cited government's political opposition as the main source.

The configuration of the news that places the government as a dominant source in news related to Covid-19 is in line with the findings of previous studies and literature (Heychael \& Rizky, 2020; Ramli \& Latif, 2019; Loisa, Susanto,
Junaidi, \& Loekman, 2019; Oktavianti, 2016). News reporting in Indonesia in general tends to place the government as a major source, where in quantity government sources will be given more space than other sources (Ramli \& Latif, 2019; Loisa et al., 2019). This shows there is a power relationship between the media and government officials in the structure of media coverage in Indonesia (Loisa et al., 2019).

\section{Tone to Government (RQ2)}

Based on a scale of -2 to 2, the average tone of news reports towards the government is 0.214 . This shows that overall news related to the government has a tone that tends to be positive. However, based on the chart we can see after February 21 and especially in March, the average tone of reporting about the government becomes repeatedly negative. Previously on January 18 and 19 the tone of news reports towards the government was also negative, but this was due to the small number of news reports (January 18: 1 news and January 19: 2 news).

Overall fluctuations occurred in the average tone of news reports towards the government. The tone about the government in January was at an average of 0.385 , while in February it was at an average rate of 0.359 , only in March experienced a fall in the average with a score of 0.116 . This shows that overall there was a decrease in the positive tone of news reports towards the government from January to March.

If cross-tabulation analysis is conducted between the tone of news reports towards the government and the main source of news reports, it is found that only the average news reports with the Indonesian government as the main source, would have a positive tone $(0.376)$ from a scale of -2 to 2 (five-point Likert scale). While the news that does not use the Indonesian government as a source, has an average negative tone of coverage. News that makes non-Indonesian governmental authorities as the main source has an average tone of -0.005 , 


\section{Graph 3.}

Average Tone of detik.com Covid-19 News Coverage Towards the Government

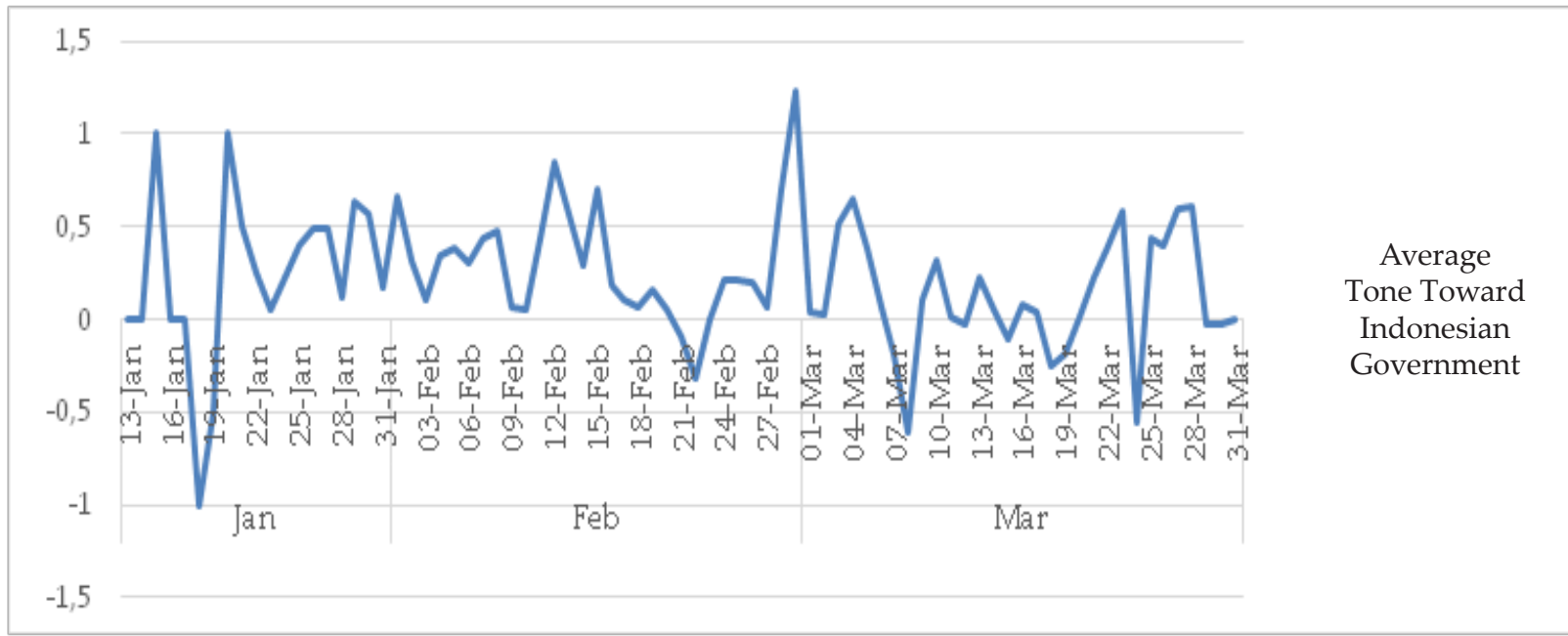

Source: Obtained from the results of the codification.

\section{Graph 4.}

Average Tone of detik.com Covid-19 News Coverage Towards the Indonesian

Government Based on Main News Source

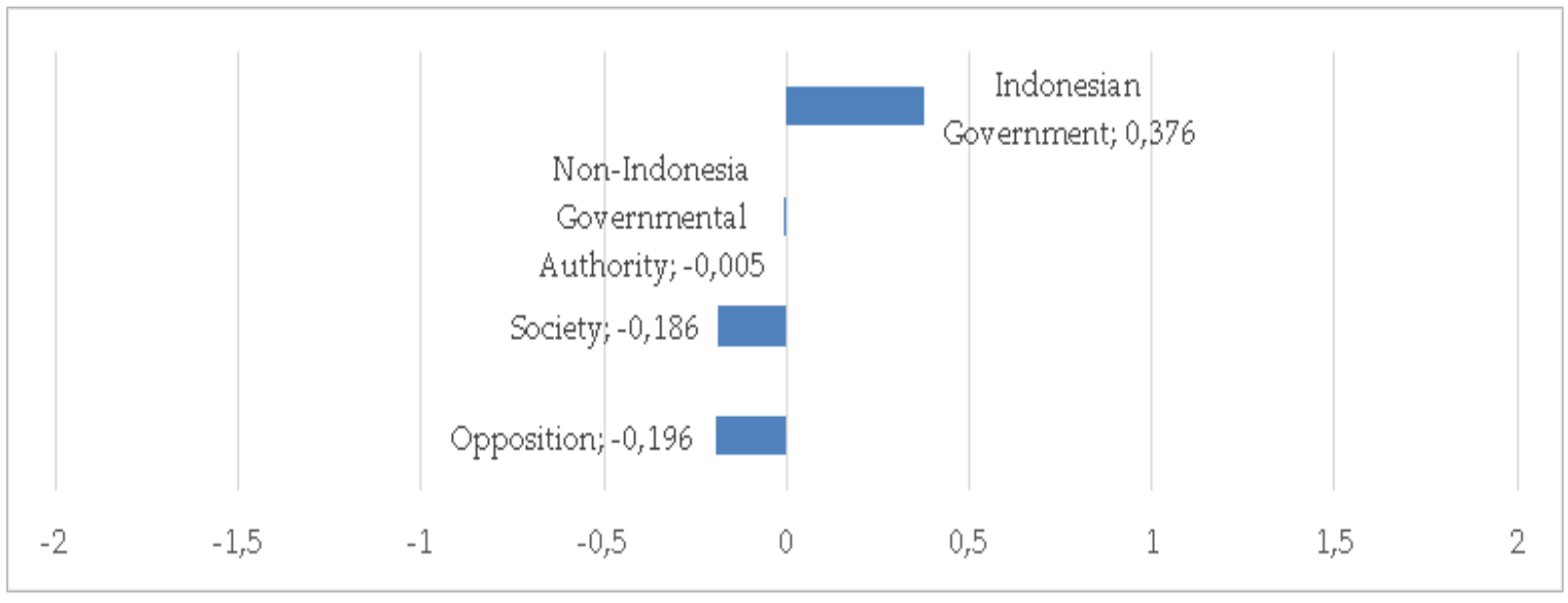

Source: Obtained from the results of the codification.

news that makes the representation of the society as the main source has an average tone of -0.186 , while news that uses the political opposition of the government as the main source has an average tone of $-0,196$.

Based on graph 3, we can see that the main source is a very significant factor and determines how the tone of the government works in news reports. detik.com tends to frame the news about the Covid-19 pandemic crisis in a positive tone by using the government as its news source. While detik.com tends to frame negative coverage of the Covid-19 pandemic crisis, using the society and the political opposition as the main sources of its reporting. The narratives that come out from elements of society and the political opposition, and were quoted by detik.com in their news, tend to doubt and challenge government policies, measures and statements.

On the other hand, the news that put non-Indonesian governmental authorities as 
its main source has a negative number (-0.005) that is not too far from the number 0 , which represents the neutrality of the news tone. detik.com tends to be balanced when quoting sources from non-Indonesian governmental authorities.

The continuous decline in the average news tone about the government, from January to March, is similar to the findings in the study of Brunken (2006) when analyzing the tone of the news about the government's response to Hurricane Katarina. The high number of predisaster reports tends to be caused by various promises and claims of success issued by the government. However, when these promises were deemed not fulfilled by the government, the tone of the news tended to become more negative in the following weeks (Brunken, 2006). In the context of the Covid-19 pandemic in Indonesia, government's efforts to prevent the entry of pandemic and claims of success was denied in March, since the first patient with Covid-19 in Indonesia was identified, and the number of patients in Indonesia continued to increase. This then decreased the tone of the news toward the government. News that gives an average positive tone towards the government only happens when representatives of the government become the news source.

\section{Crisis Frames (RQ3)}

Based on the data, frame of attribution of responsibility is the most dominant frame in the news regarding the Covid-19 pandemic crisis on detik.com, where some news has more than one frame. Despite fluctuations in the news reports frame, frame of attribution of responsibility almost always occupies a dominant position. In January, 452 of the total 1252 news stories had a frame of attribution of responsibility; followed by a frame of human interest with 328 news stories; frame of morality with 221 news articles; frame of conflict with 126 news stories and frame of economic consequences with 125 news articles.
In February the configuration changed, where previously the frame of economic consequences occupies the lowest position, in February it skyrocketed to third position. This is due to elements of the government intensively raising narratives about the economic impact of the Covid-19 pandemic crisis and health mitigation on various occasions. Consecutively in February, there were 1518 news stories out of a total of 3846 news stories which had a frame of attribution of responsibility; followed by a frame of human interest with 737 news stories; frame of economic consequences with 563 news reports; frame of conflict 534 news stories and frame of morality 494 news articles.

In March the frame configuration changed again, where the frame of morality that was previously in the lowest position in February, returned to third position. This is due to the announcement of the first 2 Indonesian citizens who were affected by the Covid-19 pandemic crisis, as well as an increasing number of patients per day. Proximity plays a significant role, with Covid-19 beginning to infect the Indonesian population. While in March the frame of consequences stagnated in the range of 500-ish news reports. Successively in March, there were 3362 news stories with frame of consequences from the total of 8518 news reports; frame of human interest with 1998 news stories; frame of morality with 1518 news stories; frame of conflict with 1063 and frame of economic consequences with 577 news reports.

Overall, the frame of attribution of responsibility contained in 5332 news reports out of a total of 6713 news articles $(79.42 \%)$; frame of human interest contained in 3063 news reports $(45.63 \%)$; frame of morality contained in 2233 news stories (33.26\%); frame of conflict is found in 1723 news reports $(25.67 \%)$ and frame of economic consequences is found in 1265 news reports (18.84\%).

If the cross-tabulation analysis is applied to the type of framing and reporting with the main source, we can see that news reports 


\section{Graph 5.}

\section{Configuration of Crisis Frames on detik.com Covid-19 News Coverage}

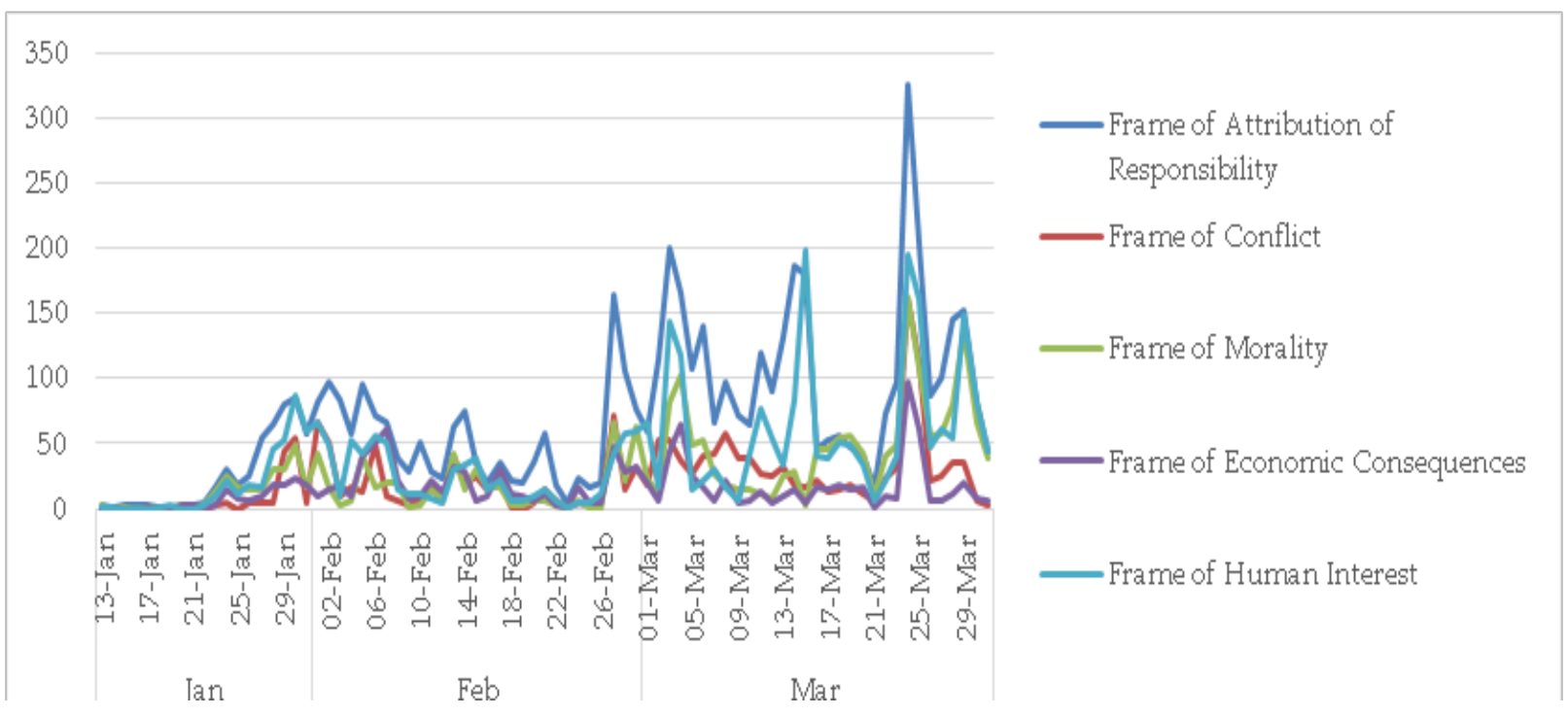

Source: Obtained from the results of the codification.

with the government as the main source is dominated by the frame of attribution of responsibility $(84.28 \%$ of the news with the government as the main source) and in the second place the frame of human interest (41.29\% of news with the government as the main source). Followed by a frame of morality $(30.62 \%)$, frame of conflict $(24.68 \%)$ and frame of economic consequences (16.36\%).

The percentage and dominant position of the frame changes most often for nonIndonesian governmental authorities shifts the frame of human interest and becomes a larger portion, which is $47.62 \%$ of news with non-Indonesian governmental authorities as the main source, and the frame of attribution of responsibility has decreased to $77.00 \%$ of the news with non-Indonesian governmental authorities as the main source.

In news reports with the political opposition element as the news source, the frame of human interest has increased in percentage. $58.02 \%$ news with the political opposition element as the main source using the frame of human interest, while the frame of attribution of responsibility has decreased when compared to news reports where the Indonesian government and non-Indonesian governmental authorities are $66.51 \%$. There is something different compared to the news with the placement of other main sources, reporting with the opposition as the main source, has a high percentage of frame morality that is $54.48 \%$.

While in news articles with elements from the society as the main source, the frame of human interest is more dominant than the others, which is $63.78 \%$. It is common that elements of general society tend to use emotional and humanist narratives towards crisis (An \& Gower, 2009; Kim \& Cameron, 2011). In second place is the frame of attribution of responsibility with $58.89 \%$. The percentage of frame of morality from the society as the main source of the news, is still larger than the percentage of frame of morality when the government and non-Indonesian governmental authorities became the main source of the news.

The findings regarding this crisis frame are similar to studies of Semetko and Valkenburg (2000) and An and Gower (2009), where attribution of responsibility always ranks first. Not surprisingly, when reporting on a crisis, the news media tend to assign specific 
Graph 6.

Configuration of Crisis Frames Based on Main News Sources

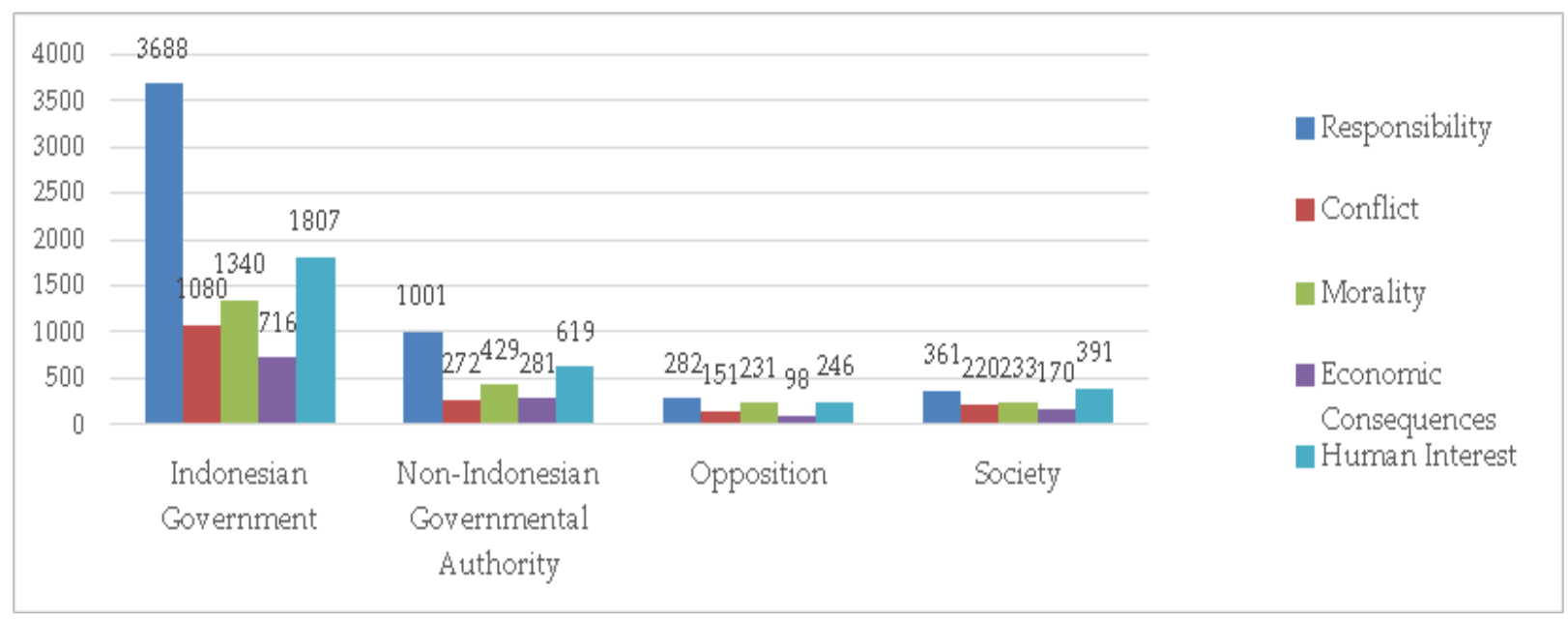

Source: Obtained from the results of the codification.

Table 2.

Percentages of Crisis Frames Based on Main News Sources

\begin{tabular}{cccccc}
\hline News Source/Informant & $\begin{array}{c}\text { Attribution of } \\
\text { Responsibility }\end{array}$ & Conflict & Morality & $\begin{array}{c}\text { Economic } \\
\text { Consequences }\end{array}$ & $\begin{array}{c}\text { Human } \\
\text { Interest }\end{array}$ \\
\hline Indonesian Government & 84,28 & 24,68 & 30,62 & 16,36 & 41,29 \\
$\quad$ Non-Indonesian & 77,00 & 20,92 & 33,00 & 21,62 & 47,62 \\
Governmental Authority & 66,51 & 35,61 & 54,48 & 23,11 & 58,02 \\
$\quad$ Political Opposition & 58,89 & 35,89 & 38,01 & 27,73 & 63,78 \\
$\quad$ Society & & &
\end{tabular}

Source: Obtained from the results of the codification.

blame to the individual or organization and to attribute responsibility for the crisis. Thus, the news media are more likely to focus on attribution of responsibility in crisis situations in which there is strong controllability and intentionality on the part of the actor (An \& Gower, 2009). The most significant difference is that in the An and Gower study (2009), the economic consequences rank second, whereas in this study it is found that the economic consequences rank last. This was due to the fact that there had been considerable upheaval from the Indonesian public at the start of the pandemic in the world while the government tended to focus on economic arguments and policies rather than health. Media in Indonesia responded to this by minimizing the frame of economic consequences in their reporting.

\section{Thematic/Episodic Frame (RQ4)}

Based on the data, the dominant frame in the news related to the Covid-19 pandemic crisis on detik.com uses episodic frames rather than thematic frames. In January, 359 from 564 news stories (63.65\%) used episodic frames, while 205 news articles (36.35\%) used thematic frames.

In February the comparison between thematic frames and episodic frames tended to be balanced; 1031 (49.28\%) news stories used thematic frames, while 1061 (50.71\%) news articles used episodic frames. This was because in February; Indonesia did not yet have a Covid-19 case. While the Covid-19 pandemic crisis has spread to various countries, including crippling various cities and countries in the world such as Italy, South Korea, Iran, etc. This is what made the news that raised issues related to the Covid-19 pandemic crisis try to 
contextualize threats in Indonesia with a larger thematic picture, especially comparing the risks and situations in Indonesia with what is happening in other countries.

Whereas in March, episodic frames jumped dramatically when compared to thematic frames. Coverage with episodic frames in March totaled 2360 (58.17\%), while news with thematic frames totaled 1697 (41.83\%). Based on the graph 7 , there was a significant increase in news coverage with thematic frames at one moment: on March 24th. This coincided with the first increase in the number of Covid-19 infected cases in Indonesia exceeding 100, from 579 to 686 people.

In total there were $3780(56.30 \%)$ news stories out of a total of 6713 news stories using episodic frames. While only 2933 (43.70\%) of the coverage uses thematic frames. This is consistent with studies that have been done before, that the news in Indonesian online media tends to be specific and partial (episodic), compared to a comprehensive and holistic reporting approach (Adiprasetio, 2019).

When a cross-tabulation analysis was performed between thematic / episodic frames with news tones, it was found that episodic frames had higher average of positive tone (0.287) compared to the tone of news stories with thematic frames (0.120).

This shows that news with episodic frames tends to benefit the government compared to thematic frames. News that releases the general context makes the tone of the government more positive when compared to news that emphasizes specific aspects of events. This finding is in line with a study conducted by Heychael and Rizky (2020) with different analysis objects. Journalism reporting in Indonesia tends to focus on situational events and ignore the large context that covers it.

\section{Conclusion}

This study recognized the use of framing on the media, tone, and offered a better understanding of how online media portrayed the government during a pandemic. Media plays a very important role in framing the crisis as news, by giving broad stories about meaning, social and political (Miller \& Goidel, 2009). In a crisis situation such as the Covid-19 pandemic crisis, detik.com as the media would

\section{Graph 7.}

\section{The Fluctuation of Thematic/Episodic Frames}

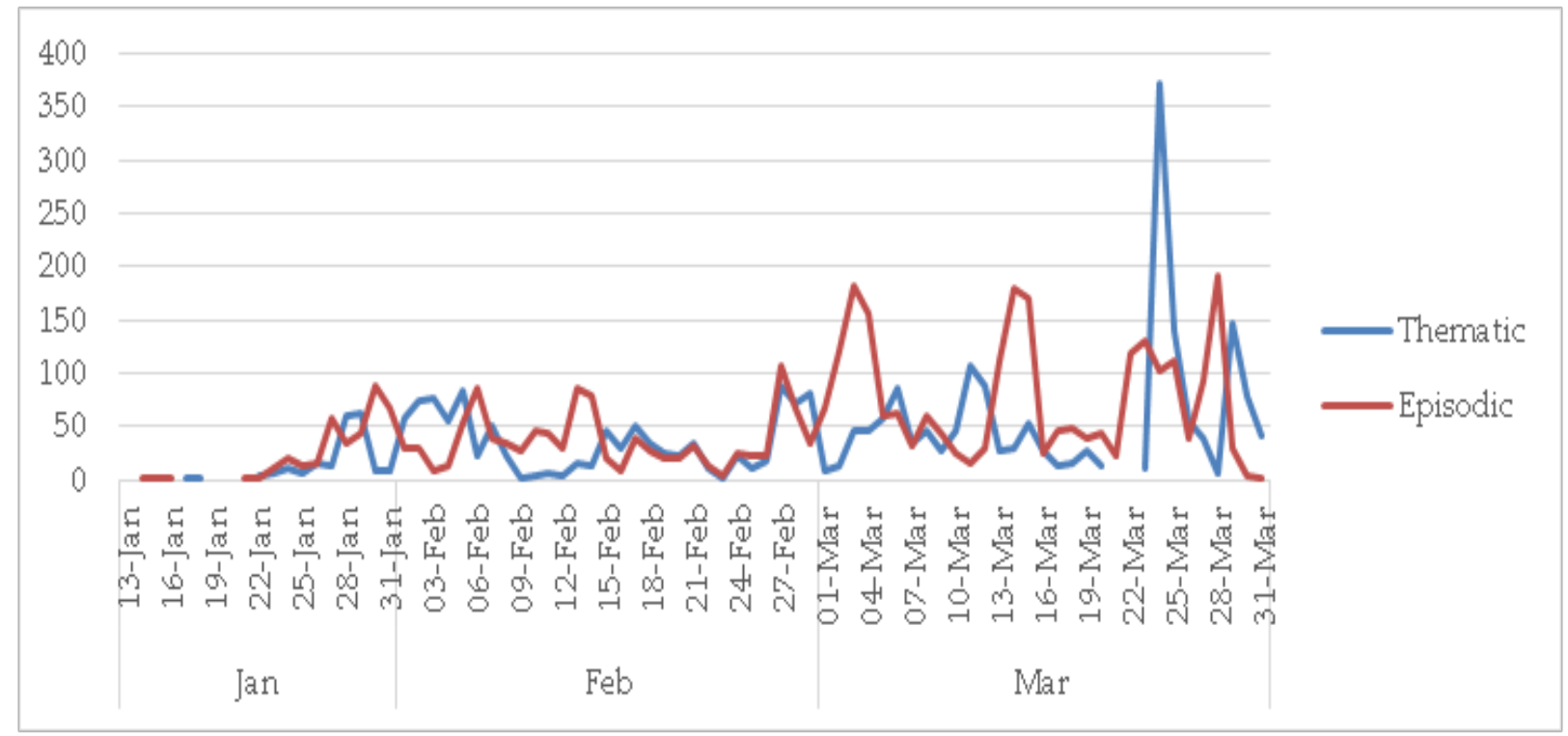

Source: Obtained from the results of the codification. 
Graph 8.

Average of Tone Toward Indonesian Government Based on Thematic/Episodic Frames

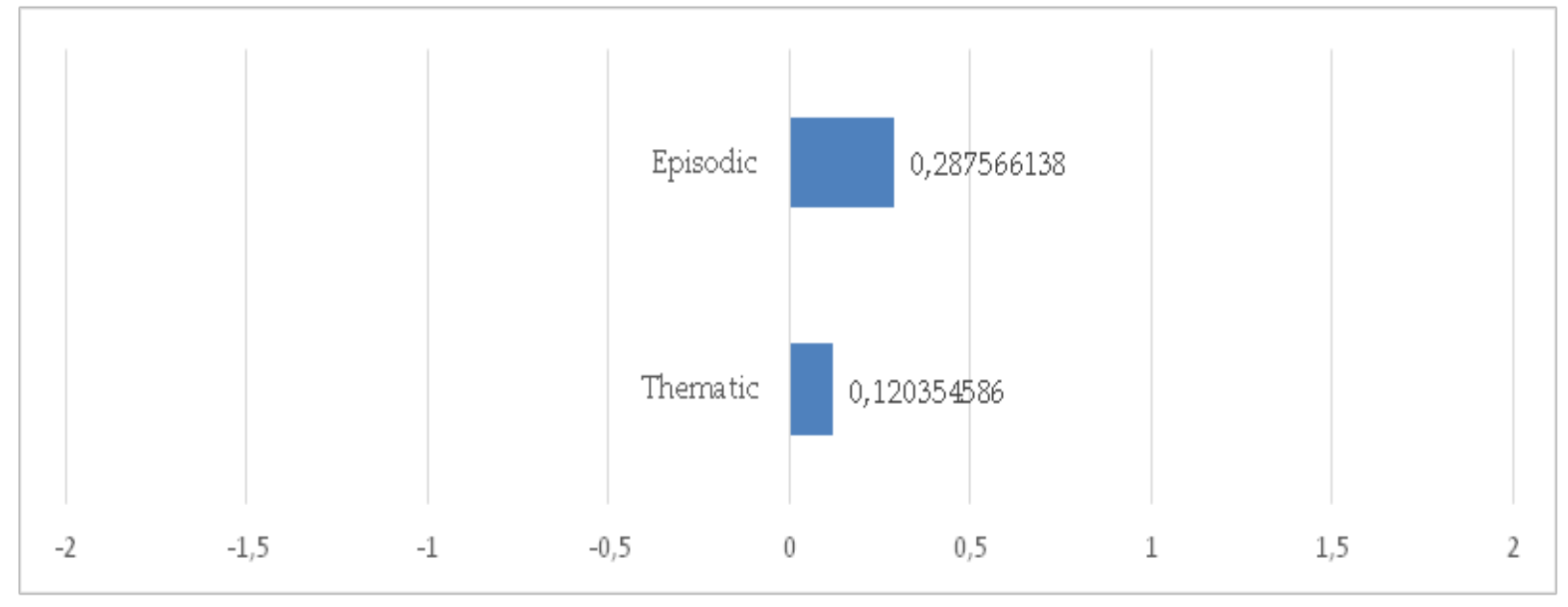

Source: Obtained from the results of the codification.

seek information about the crisis and try to evaluate the event and find who is most responsible for the crisis.

The results of this study indicate that the frame of attribution of responsibility is not only the most widely used by detik.com, but also the most dominant when the government is the main source of the news. The form of attribution of responsibility in times of crisis tends to be stronger in the realm of government because catastrophic events are widespread, forming an experience felt at the national level. Now the spread of the Covid-19 pandemic crisis has touched all provinces in Indonesia. As a result, catastrophic events have the potential to become political symbols in the long run used in framing various debates in a policy (Jennings, 1999).

Based on the result we can see how detik.com has a pragmatic character. Being dominated by news reports in the form of straight news, we can see how detik.com tends to provide space for the government to convey its narrative. This is likely to be influenced by access: statements from government representatives through press conferences, press releases, formal interviews and doorstop interviews are much easier to obtain compared to other news sources. The speed demands of news that are characteristic of detik.com make this pragmatism an inevitable part of the detik. com editorial mechanism. Pragmatism, which is in a normal or even pre-crisis situation, is very vulnerable to be used by the government to influence public opinion. Even so, detik. com's pragmatism eventually followed the situation, especially after March 2, 2020 when President Joko Widodo announced the first two Indonesian citizens who tested positive in Depok, West Java, where the tone towards the government slowly became more negative by detik.com, following public disappointment with the government which failed to contain the spread of the Covid-19 pandemic to Indonesia.

The more negative tone of news toward the government from January to March indicated a change in detik.com's response to government actions in handling the Covid-19 pandemic crisis. One of the events that contributed to the decreasing tone of news toward government was the identification of the first patient infected with Covid-19. Other events later destroyed various anticipatory narratives as well as arrogant claims issued by the government in January and February. This was exacerbated by the increasing number 
of Covid-19 patients in March. This then decreased the positive tone of the news toward the government. News that gives an average positive tone towards the government, only happened when representatives of the government become sources in the news.

This study also shows that episodic frames become dominant when compared to thematic frames. The use of dominant episodic frames in news reports actually gives advantages to the government, where the tone of the government in reporting with episodic frames is more positive when compared with reporting with thematic frames. The episodic frame makes news separated from the holistic aspects of the crisis, where the government should be most responsible for prevention, mitigation and other measures.

\section{References}

Abeysinghe, S., \& White, K. (2010). Framing Disease: The Avian Influenza Pandemic in Australia. Health Sociology Review: The Journal of the Health Section of the Australian Sociological Association, 19(3), 369-381.

Abeysinghe, S., \& White, K. (2011). The avian influenza pandemic: Discourses of risk, contagion and preparation in Australia. Health, Risk \& Society Health, Risk \& Society, 13(4), 311-326.

Adiprasetio, J. (2019). Kekalahan Jurnalisme di Hadapan Pasar dan Pemasaran Daring. In Suryana, A \& et al (Eds.), Eksistensi Promosi di Era Digital (pp. 9-21). Bandung: Bitread.

Adiprasetio, J. (2020a). Covid-19: Saat Ini Kita Membutuhkan Paranoia, Lebih dari Kapanpun. Retrieved May 24, 2020, from Remotivi.id website: https://remotivi. or.id/amatan/578/covid-19-saat-ini-kitamembutuhkan-paranoia-lebih-darikapanpun

Adiprasetio, J. (2020b). Under the shadow of the state: Media framing of attacks on West Papuan students on Indonesian online media. Pacific Journalism Review, 26(2), 240-258.

An, S.-K., \& Gower, K. K. (2009). How do the news media frame crises? A content analysis of crisis news coverage. Public Relations Review Public Relations Review, 35(2), 107-112.

Basnyat, I., \& Lee, S. T. (2015). Framing of Influenza A (H1N1) pandemic in a Singaporean newspaper. Health Promotion International Health Promotion International, 30(4), 942-953.

Becker, A. B., \& Scheufele, D. A. (2011). New Voters, New Outlook? Predispositions, Social Networks, and the Changing Politics of Gay Civil Rights. Socisciequar Social Science Quarterly, 92(2), 324-345.

Ben-Porath, E. N., \& Shaker, L. K. (2010). News Images, Race, and Attribution in the Wake of Hurricane Katrina. Journal of Communication, 60(3), 466-490.

Berry, T. ., Wharf-Higgins, J., \& Naylor, P. . (2007). SARS wars: an examination of the quantity and construction of health information in the news media. Health Communication, 21(1), 35-44.

Blumer, H. (1971). Social problems as collective behavior. Social Problems, 18(3), 298-306.

Boer, K. M., Pratiwi, M. R., \& Muna, N. (2020). Analisis Framing Pemberitaan Generasi Milenial dan Pemerintah Terkait Covid-19 di Media Online. Communicatus, 4(1), 85-104.

Brunken, B. L. (2006). Hurricane Katrina: a content analysis of media framing, attribute agenda setting, and tone of government response. Louisiana State University.

Cho, S. H., \& Gower, K. K. (2006). Framing effect on the publics response to crisis: Human interest frame and crisis type influencing responsibility and blame. PUBLIC RELATIONS REVIEW, 32(4), 420-422.

Chong, D., \& Druckman, J. N. (2007). Framing Theory. Annual Review of Political Science, 
10(1), 103-126. https://doi.org/10.1146/ annurev.polisci.10.072805.103054

COVID-19 Map Johns Hopkins Coronavirus Resource Center. (2020). Retrieved May 29, 2020, from https://coronavirus.jhu. edu/map.html

D'Alessio, D., \& Allen, M. (2000). Media bias in presidential elections: a meta-analysis. JCOM Journal of Communication, 50(4), 133-156.

D'Angelo, P. (2002). News Framing as a Multiparadigmatic Research Program: A Response to Entman. JCOM Journal of Communication, 52(4), 870-888.

D'Angelo, P., \& Kuypers, J. A. (2016). Doing news framing analysis : empirical and theoretical perspectives. II II. Retrieved from https:// nls.ldls.org.uk/welcome.html?ark:/81055/ vdc_100058681739.0x000001

De Vreese, C. H. (2005). Framing Europe: television news and European integration. Amsterdam: Spinhuis.

De Vreese, C. H. (2004). Political Campaigning in Referendums : Framing the Referendum Issue. Retrieved from http://www.myilibrary. com?id=5503

Detenber, B., \& McLeod, D. (1999). Framing effects of television news coverage of social protest. Journal of Communication, 49(3), 3-23.

Dijk, T. A. van. (2011). News analysis : case studies of international and national news in the press. New york: Routledge.

Dimitrova, D. V., \& Connolly-Ahern, C. (2007). A tale of two wars: Framing analysis of online news sites in coalition countries and the Arab World during the Iraq War. Howard Journal of Communications, 18(2), 153-168. https:// doi.org/10.1080/10646170701309973

Ducharme, J. (2020). News Coverage of Coronavirus in 2020 is Very Different Than it Was For Ebola in 2018. Retrieved May 24, 2020, from Times website: https:// time.com/5779872/coronavirus-ebolanews-coverage/

Dunaway, J. (2013). "Media Ownership and Story Tone in Campaign News." American Politics Research, 41(1), 24-53. https://doi. org/10.1177/1532673X12454564

Endres, K. L. (2004). Help-Wanted Female: Editor \& Publisher Frames a Civil Rights Issue. Journalism \& Mass Communication Quarterly Journalism \& Mass Communication Quarterly, 81(1), 7-21.

Entman, R. M. (1991). Symposium Framing U.S. Coverage of International News: Contrasts in Narratives of the KAL and Iran Air Incidents. JCOM Journal of Communication, 41(4), 6-27.

Entman, R. M. (1993). Framing: Toward Clarification of a Fractured Paradigm. Journal of Communication, 43(4), 51-58.

Entman, R. M. (2007). Projections of power: framing news, public opinion, and U.S. foreign policy. Chicago; London: University of Chicago Press.

Graber, D. ., \& Dunaway, J. (2018). Mass media and American politics. Thousand Oaks: California CQ Press.

Haider-Markel, D. P., Delehanty, W., \& Beverlin, M. (2007). Media Framing and Racial Attitudes in the Aftermath of Katrina. PSJ Policy Studies Journal, 35(4), 587-605.

Hayati, H. N., \& Yoedtadi, M. . (2020). Konstruksi Berita Covid-19 di Kompas.com dan Tribunnews.com. Koneksi, 4(2), 243-250.

Hayes, A. F., \& Krippendorff, K. (2007). Answering the Call for a Standard Reliability Measure for Coding Data. Communication Methods and Measures, 1(1), 77-89.

Herlinda, O. (2020). Menimbang Peran Media dalam Menghadapi Epidemi. Retrieved May 24, 2020, from Remotivi.id2 website: https://www.remotivi.or.id/amatan/575/ menimbang-peran-media-dalammenghadapi-epidemi 
Heychael, M., \& Rizky, A. P. (2020). Lumpuh dalam Cengkeraman Cukong: Televisi dan Pemberitaan UU Cipta Kerja. Retrieved November 9, 2020, from Remotivi.id website: https://www. remotivi.or.id/pantau/643/lumpuhdalam-cengkeraman-cukong-televisidan-pemberitaan-uu-cipta-kerja

Hong, T. (2007). Information Control in Time of Crisis: The Framing of SARS in Chinabased Newspapers and Internet Sources. CyberPsychology and Behavior, 10(5), 696-699.

Iyengar, S. (1990a). Framing responsibility for political issues: The case of poverty. Polit Behav Political Behavior, 12(1), 19-40.

Iyengar, S. (1990b). The accessibility bias in politics : television news and public opinion. International Journal of Public Opinion Research., 2(1).

Iyengar, S. (1991). Is anyone responsible? : how television frames political issues. Chicago; London: The University of Chicago Press.

Jennings, M. K. (1999). Political Responses to Pain and Loss. The American Political Science Review., 93(1), 1.

Johnson-Cartee, K. S. (2005). News narratives and news framing : constructing political reality. Lanham: Rowman \& Littlefield Publishers.

Kim, H., \& Cameron, G. (2011). Emotions Matter in Crisis: The Role of Anger and Sadness in the Publics' Response to Crisis News Framing and Corporate Crisis Response. Communication Research, 38(6), 826-855.

Kiousis, S., McDevitt, M., \& Wu, X. (2005). The Genesis of Civic Awareness: Agenda Setting in Political Socialization. JCOM Journal of Communication, 55(4), 756-774.

Krippendorff, K. (2005). Content Analysis : an Introduction to Its Methodology. Thousand Oaks; London; New Delhi: Sage.

Kuypers, J. A. (2005). The art of rhetorical criticism. Boston: Pearson/ Allyn and Bacon.
Lavrakas, P. J. (2011). Encyclopedia of survey research methods. Retrieved from http:// www.credoreference.com/book/ sagesurveyr

Lecheler, S., \& De Vreese, C. . (2018). Introduction to News Framing Effects Research Theory and Practice. Taylor \& Francis.

Loisa, R., Susanto, E. H., Junaidi, A., \& Loekman, F. (2019). Media Siber, Aparat, dan Pemberitaan Keberagaman. Jurnal Aspikom: Asosiasi Pendidikan Tinggi Ilmu Komunikasi, 3(6), 1243-1253.

Margianto, J. ., \& Syaefullah, A. (2013). Media Online: Pembaca, Laba, dan Etika. Jakarta: AJI Indonesia - Ford Foundation.

McComas, K., \& Shanahan, J. (1999). Telling Stories About Global Climate Change: Measuring the Impact of Narratives on Issue Cycles. Communication Research, 26(1), 30-57. https://doi. org/10.1177/009365099026001003

Merry, M. K. (2015). Framing environmental disaster. [Place of publication not identified]: Routledge.

Miller, A., \& Goidel, R. (2009). News organizations and information gathering during a natural disaster: Lessons from Hurricane Katrina. J. Contingencies Crisis Manage. Journal of Contingencies and Crisis Management, 17(4), 266-273.

Neuman, W. R., Just, M. R., \& Crigler, A. N. (1994). Common knowledge: news and the construction of political meaning. Chicago; London: University of Chicago Press.

Nijkrake, J., Gosselt, J. F., \& Gutteling, J. M. (2015). Competing frames and tone in corporate communication versus media coverage during a crisis. PUBREL Public Relations Review, 41(1), 80-88.

Nisbet, E. C., Hart, P. S., Myers, T., \& Ellithorpe, M. (2013). Attitude Change in Competitive Framing Environments? Open-/ClosedMindedness, Framing Effects, and Climate Change. JCOM Journal of Communication, 63(4), 766-785. 
Norris, P., Kern, M., \& Just, M. R. (2003). Framing terrorism : understanding terrorist threats and mass media. New York; London: Routledge.

Oktavianti, R. (2016). Reportase dalam Hegemoni Pemerintah dan Media: Studi Kasus Jurnalis Kepresidenan Era Soeharto dan Joko Widodo. Jurnal Komunikasi Indonesia, $V(1)$, 37-47.

Palupi, M. F. T., \& Irawan, R. E. (2020). Analisis Framing Pemberitaan Kebijakan Pemerintah Terkait Ketenagakerjaan sebagai Dampak Covid 19 di Kompas.com dan Malaysiakini. Jurnal Representamen, 6(2), 8-22.

Pan, Z., \& Kosicki, G. (1993). Framing analysis: An approach to news discourse. Political Comm. Political Communication, 10(1), 55-75.

Papacharissi, Z., \& Oliveira, M. deF. (2008). News frames terrorism a comparative analysis of frames employed in terrorism coverage in U.S. and U.K. newspapers. The International Journal of Press, Politics, 13.

Peta Sebaran COVID-19. (2020). Retrieved May 29, 2020, from Gugus Tugas Percepatan Penanganan COVID-19 Indonesia website: https://covid19.go.id/peta-sebaran

Pfau, B. M., Haigh, M., Gettle, M., Donnelly, M., Scoff, G., Warr, D., \& Wiffenberg, E. (2015). Combats Unit : ImpactOn Newspaper And Tone. Journalism $\mathcal{E}$ Mass Communication Quarterly, 81(1), 74-88. https://doi. org/10.1177/107769900408100106
Poindexter, P. M., Smith, L., \& Heider, D. (2003). Race and Ethnicity in local Television News: Framing, Story Assignments, and Source Selections. Journal of Broadcasting E Electronic Media, 47(4), 524-536.

Price, V., \& Tewksbury, D. (1997). News values and public opinion: A theoretical account of media priming and framing.

Ramli, R., \& Latif, D. (2019). Kecenderungan Pilihan Narasumber dan Posisi Berita Demonstrasi pada Surat Kabar Harian Fajar. Komunikologi: Jurnal Ilmiah Ilmu Komunikasi, 16(2), 112-118.

Semetko, H. ., \& Valkenburg, P. (2000). Framing European politics: a content analysis of press and television news. Journal of Communication, 50(2), 93-103.

Shoemaker, P. J., \& Reese, S. D. (2014). Mediating the message in the 21st century a media sociology perspective. New York \& London: Routledge.

Tankard, J. . (2001). The empirical approach to the study of media framing. In S. . Reese, A. . Grant, \& O. . Gandy Jr (Eds.), Framing public life perspectives on media and our understanding of the social world (pp. 95-106). New York \& London: Routledge. Waldman, P., \& Devitt, J. (1998). Newspaper Photographs and the 1996 Presidential Election:TheQuestion ofBias.JOURNALISM AND MASS COMMUNICATION QUARTERLY, 75(2), 302-311. 